\section{Hyaluronidase Applied to the Gingiva of Rhesus Monkeys}

by

FREDERIC N. SMITH,* D.D.S., M.S.

Sigurd P. RAMfJORD,* L.D.S., Ph.D.

\section{INTRODUCTION}

MICROORGANISMS of dental plaque have been implicated as an important factor in the initiation and progression of the inflammatory lesions typically seen in periodontal disease. ${ }^{1-5}$ The inflammatory potential of plaque microorganisms may be due to their ability to elaborate toxins, enzymes and/or other metabolites. Certain of these extramicrobial substances may be capable of penetrating the barrier of the crevicular epithelium and the epithelial attachment, thereby allowing many potentially noxious substances access to the underlying connective tissue resulting in an inflammatory response.

Hyaluronidase (Hase) is one of several enzymes elaborated by microorganisms of dental plaque. ${ }^{6-10}$ Hase is capable of depolymerizing hyaluronic acid, an important mucopolysaccharide constituent of both the ground substance of connective tissue ${ }^{11-13}$ and the intercellular cementing substance of the epithelium. ${ }^{14-17}$

Substantial lysosomal Hase activity has also been found in polymorphonuclear leukocytes. ${ }^{18}$ Thus, once the periodontal inflammatory process has been initiated, Hase released from polymorphonuclear leukocytes is in a position to influence the progression of the lesion. Hase may, therefore, affect the periodontal lesions both from the external (bacterial source) and from the internal (lysosomal source) environments.

The effects of Hase upon the periodontal tissues have been studied by several investigators. ${ }^{16,19-23}$ In vivo topical application of Hase containing solutions has resulted in widening of the intercellular spaces of the gingival epithelium. ${ }^{20,21}$ This epithelial "loosening" effect has been found by electron microscopy to be accentuated by the application of a combination of Hase plus leukocytic homogenate. ${ }^{21}$ Loosening of the epithelium appears to have been responsible for allowing trypan blue dye to penetrate several cell layers into the gingival sulcus lining after only two daily applications of a Hase solution. ${ }^{23}$ Hase application was also capable of increasing the turnover rate of the sulcular epithelium

\footnotetext{
*Department of Periodontics, The University of Michigan School of Dentistry, and VA Hospital, Ann Arbor, Michigan.
}

as demonstrated by an average radioactive index (after in vivo uptake of $\mathrm{H}^{3}$-thymidine) $2 \frac{1}{2}$ times greater than normal. ${ }^{23}$ The epithelial attachment has been shown to be unaffected by short-term Hase application. ${ }^{23}$

Since Hase has been implicated as a possible factor in the etiology of periodontal disease, its long-time periodontal effect was studied in monkeys.

\section{MAterials AND Methods}

Two young adult male rhesus monkeys (Maccacca mulatta) with complete adult dentitions, weighing 14 and 16 pounds, were used in this study.

A $100 \mathrm{mg} \%$ hyaluronidase solution for topical application was prepared fresh each experimental week by dissolution of $15 \mathrm{mg}$ of bovine testicular hyaluronidase, type III (Sigma Chemical Co., 388 NF units/mg) in 15 $\mathrm{ml}$ of isotonic $\mathrm{NaCl}$ solution U.S.P. The hyaluronidase powder and aqueous solution were refrigerated at $-20^{\circ}$ and $4^{\circ} \mathrm{C}$, respectively, when not in use.

Verification of the activity of the topical hyaluronidase solution was periodically done utilizing the turbidimetric method of DeFerrante. ${ }^{24}$

Experimental animal No. 1 received topical applications of the hyaluronidase solution on the right maxillary and mandibular one-half arches while animal No. 2 received the hyaluronidase on the left maxillary and mandibular half-arches. The opposite half-arches of each animal served as control receiving topical applications of the isotonic $\mathrm{NaCl}$ vehicle alone.

Twice weekly applications of the hyaluronidase and control solutions were done while the animals were under general anesthesia with sodium nembutal $(50 \mathrm{mg} / 4$ lb. body weight). With the head of the animal in a position to allow gravitational forces to flow the solutions into the gingival sulci, topical applications were made dropwise with disposable Pasteur pipettes over the crowns of the teeth. The hyaluronidase containing solution was applied to the appropriate half-arch and the control solution applied immediately afterwards to the other half-arch. Applications were repeated every five minutes. Six applications were made each experimental day. After completion of the lower arch applications, the animals were repositioned and the applications applied to the upper arches in an analogous manner. During the entire procedure, the periodontal structures remained moist. Care was exercised to avoid cross-over of the hyaluronidase solution at the midline.

After six months on this experimental schedule, the animals were sacrificed by exsanguination under general anesthesia. The heads were removed, and the jaws separated from the rest of the calvarium. The jaws were then fixed in neutral buffered formalin (10\%) for 
three weeks. Specimens of lung, liver, heart, stomach, large and small intestines, pancreas, spleen, adrenals and kidneys were also obtained at sacrifice for histological examination to rule out systemic disease.

After fixation, the jaws were rinsed overnight in running tap water and then cut into buccolingual sections, 2-3 mm thick and parallel to the long axes of the teeth. These sections were then decalcified in $10 \%$ formic acid for three to four weeks. After rinsing, the sections were imbedded in paraplast, cut into six micron sections, mounted on glass slides, and stained with Ehrlich's acid hemotoxylin and eosin. Care was exercised to section the teeth and periodontium buccolingually, parallel to the long axis of each tooth.

Histologic measurements were made on the buccal and lingual of the teeth in the posterior segments, starting with the first premolars. The extreme buccal and lingual curvature portions of each tooth were selected for evaluation. Care was exercised to avoid the interradicular areas of multirooted teeth. Histometric measurements were made for the cementoenamel junction (CEJ) to the base of the epithelial attachment (EA), from the base of the gingival crevice to the apical base of the EA (EA length), and from the free gingival margin (FGM) to the base of the gingival crevice. Measurements were made to the nearest $0.01 \mathrm{~mm}$ with an ocular micrometer* calibrated to the nearest micron.

The degree of inflammatory cell infiltrate was evaluated by the Inflammatory Index (I.I.) of Ramfjord and Demitriou. ${ }^{25}$ The I.I. were counted at the base of the crevice and the apical base of the EA on the same sections used for histometric measurements.

For the determination of the I.I., the microscopic field was placed so that one-half of the field consisted of epithelium and the other half of subepithelial connective tissue. At a magnification of 450 diameters the total number of extravascular inflammatory cells in the connective tissue was then counted. The total number of connective tissue cells in the same field was subsequently counted. The intravascular cells were not included in either count. The plane of focus was not changed during the counting procedure. No attempt was made to differentiate between types of inflammatory cells. The I.I. was then calculated by dividing the total number of extravascular inflammatory cells by the total number of extravascular cells in each field and multiplying by 100 .

Experimental and control "total means" were calculated for each of the three areas of histometric measurements for each of the two animals. A mean Inflammatory Index was calculated at each of the I.I. counting

\footnotetext{
*Bausch \& Lomb.
}

locations utilizing the combined data from each experimental animal. The means were then analyzed for statistically significant differences ultilizing the $F$ and Student's $t$ tests.

\section{RESULTS}

No systemic disease was noted in either animal. Monkey No. 2 demonstrated a greater accumulation of plaque and calculus than did monkey No. 1. No epithelial "loosening" of the gingival sulcus epithelium could be observed by light microscopy after the long-term Hase application.

\section{Histometric Measurements}

The results for each experimental animal are shown in Table 1 and Figure 1 . No significant differences could be ascertained between control and experimental means in either animal in any of the three measurements.

The average gingival crevice depths for both animals were nearly equal on both the experimental and control sides at about $0.43 \mathrm{~mm}$. The average epithelial attachment lengths of 1.13 and $0.85 \mathrm{~mm}$ were also very similar. Monkey No. 1, however, demonstrated only a very slight apical migration of the epithelial attachment from the cementoenamel junction $(0.26 \mathrm{~mm})$, while the other monkey showed a significantly greater downgrowth of the epithelial attachment $(0.82 \mathrm{~mm}), \mathrm{P}<0.05$.

Thus, even though the periodontal sulci were more apical in monkey No. 2, the relationship between the gingival crevice depth and length of the epithelial attachment remained very constant for both animals.

\section{Inflammatory Indices}

The mean total I.I. at the base of the gingival sulcus following Hase application $(21.48 \pm 2.20)$ was significantly greater than the I.I. from the control sides ( 14.02 \pm 1.85 ), $P<0.05$, Figure 2 and Table 2.

The I.I. at the base of the epithelial attachment did not differ significantly between control and experimental (Hase) sides.

The I.I. was always significantly greater at the base of the gingival sulcus than at the apical base of the epithelial attachment, both for the control and experimental sides, Figure 2.

\section{Discussion}

The Hase used in this investigation is more closely related to Hase derived from lysosomal sources than to the bacterial enzyme. Lysosomal Hase is active at a lower $\mathrm{pH}$ than is bacterial Hase. ${ }^{26,27}$ Non-bacterial Hase, derived from gingivectomy tissue after incubation in 
TABLE 1

Total mean of histometric measurements with standard errors.

TOTAL MEAN GINGIVAL CREVICE DEPTH (millimeters)

Monkey \#1

\begin{tabular}{|c|c|}
\hline Experimental & Control \\
\hline $0.45 \pm 0.08$ & $0.44 \pm 0.08$ \\
\hline
\end{tabular}

Monkey \#2

\begin{tabular}{|c|c|}
\hline Experimental & Control \\
\hline $0.44 \pm 0.04$ & $0.40 \pm 0.05$ \\
\hline
\end{tabular}

TOTAL MEAN LENGTH OF EPITHELIAL ATTACHMENT (millimeters)

Monkey \#1

\begin{tabular}{|c|c|}
\hline Experimental & Control \\
\hline $1.07 \pm 0.05$ & $1.19 \pm 0.08$ \\
\hline
\end{tabular}

Monke y \#2

\begin{tabular}{|c|c|}
\hline Experimental & Control \\
\hline $0.82 \pm 0.06$ & $0.88 \pm 0.06$ \\
\hline
\end{tabular}

TOTAL MEAN CEMENTOENAMEL JUNCTION TO APICAL BASE OF EPITHELIAL ATTACHMENT (millimeters)

\begin{tabular}{|c|c|}
\multicolumn{2}{|c}{ Monkey \#1 } \\
\hline Experimental & Control \\
\hline $0.23 \pm 0.07$ & $0.30 \pm 0.09$ \\
\hline
\end{tabular}

Monkey \#2

\begin{tabular}{|c|c|}
\hline Experimental & Control \\
\hline $0.73 \pm 0.10$ & $0.90 \pm 0.15$ \\
\hline
\end{tabular}

antibiotics, has maximum activity at $\mathrm{pH} 3.5-4.0 . .^{28}$ This low $\mathrm{pH}$ but maximum Hase activity range agrees with findings from lysosomal Hase derived from liver and bone homogenates. ${ }^{26,}{ }^{29}$ Bacterial Hase apparently has little activity at a $\mathrm{pH}$ less than 4.5-5.0.30-37 Several molecular forms of Hase have recently been isolated from dental plaque and all appear to be of bacterial origin. ${ }^{33,}$ 38-40

Although there are four officially recognized types of Hases, ${ }^{41}$ all probably lead to the same in vivo effects, i.e., degradation of the substrate with sequelae appropriate to the area of enzymatic damage. Thus, the experimental changes observed with one form of Hase are probably analogous to those seen with another type of Hase.

The $\mathrm{pH}$ of the Hase solution used in this study was 4.5. In agreement with others, ${ }^{27}$ turbidimetric assay of the testicular Hase solution proved that it had retained its activity. At this $\mathrm{pH}$ Hase has been found to have a
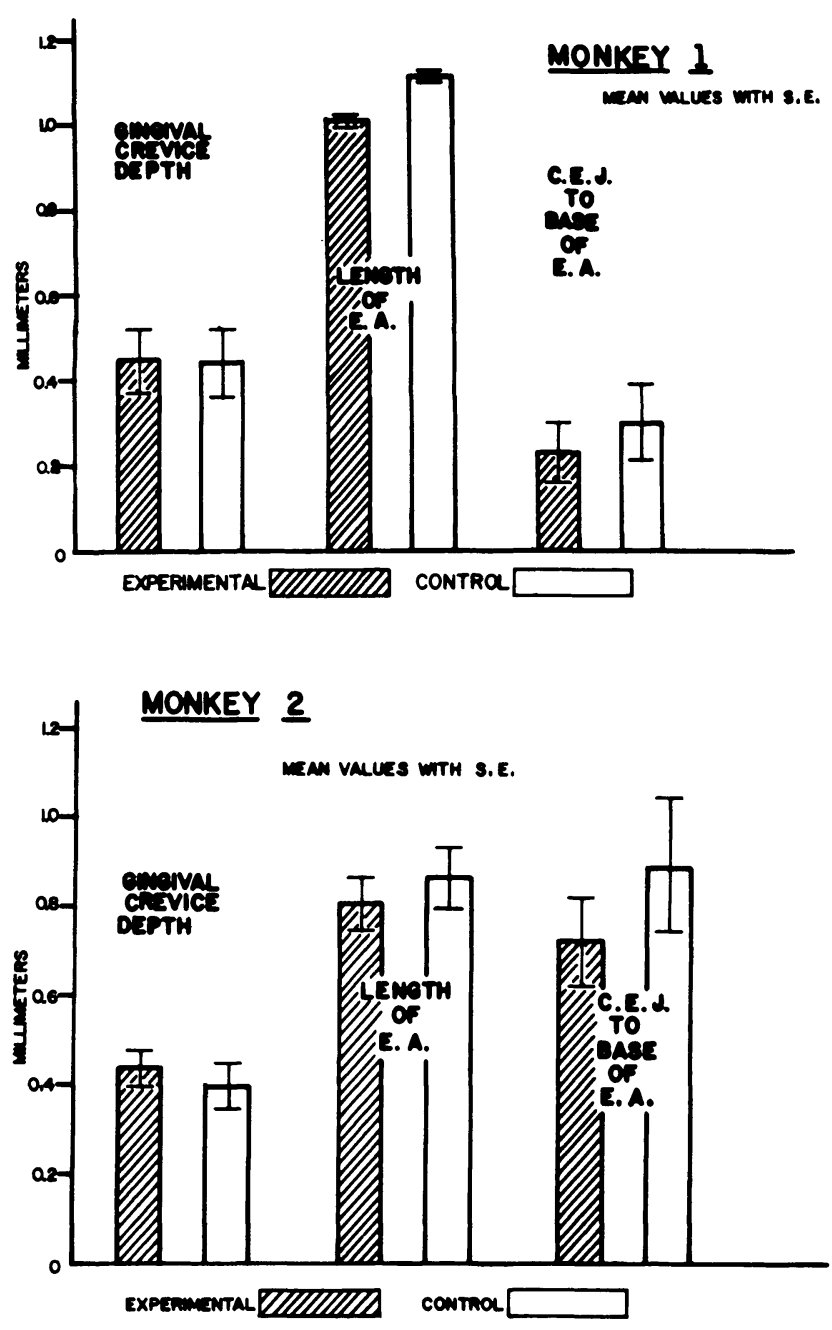

Figure 1. Total mean histometric measurements for experimental animals with standard error (S.E.) bars. E.A. epithelial attachment, C.E.J.-cementoenamel junction.

remarkably consistent activity over a wide range of $\mathrm{NaCl}$ concentrations. ${ }^{27}$ The isotonic $\mathrm{NaCl}$ vehicle had a $\mathrm{pH}$ of 6.1 . This discrepancy of $1.6 \mathrm{pH}$ units was of some concern. However, in light of the findings in Awwa and Stallard, ${ }^{42}$ it is unlikely that the changes observed at the base of the gingival crevice could be due to this minor $\mathrm{pH}$ differential. These investigators found that topical applications of lactic acid at a $\mathrm{pH}$ of 4.0 had no effect on the gingival sulcus or epithelial attachment when compared to a pH 7.0 control solution.

\section{Histometric Measurements}

When compared to controls, the epithelial attachment was not positioned more apically, nor was the gingival sulcus depth increased after the six month, biweekly application of Hase. However, Hase cannot be completely excluded as a factor contributing to periodontal destruction. 
TABLE 2

MEAN TOTAL INFLAMMATORY INDICES

Base of Gingival Crevice

(in millimeters $\pm s$ tandard error)

Experimental $\ldots \ldots \ldots+2.21 .48 \pm 2.20$

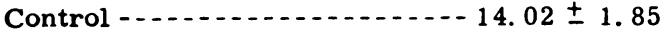

Apical Base of Epithelial Attachment

(in millimeters \pm standard error)

Experimental-....... $9.55 \pm 1.84$

Control $\ldots \ldots \ldots+7.40 \pm 1.26$

**Significant at the $95 \%$ level of confidence

It was evident that monkey No. 2 had accumulated a significantly greater amount of local irritants during the study than did monkey No. 1. This is probably the reason for the more apical migration of the base of the epithelial attachment in monkey No. 2. However, gingival recession apparently kept pace with the apical migration of the epithelial attachment in monkey No. 2 as no difference in gingival crevice depths was seen between the two animals.

\section{Inflammatory Indices}

The hypothesis that Hase applications will increase the spread of inflammation is supported by the total mean I.I. at the base of the gingival crevice. This finding is in agreement with Murphy and Stallard. ${ }^{23}$

The inflammation at the apical base of the epithelial attachment was not affected by Hase application. This is also in agreement with Murphy and Stallard. ${ }^{23}$

Within the limitations of this long-term application schedule, it is evident that Hase may be a factor in the spread of inflammation at the base of the gingival sulcus. The use of relatively young, adult monkeys with basically healthy periodontium meant that whatever changes were observed were probably related to the early phases of periodontal destruction. The effects of Hase over a longer period of time, or with a more frequent application schedule, might be anticipated to show a greater effect within the gingival sulcus.

Thus, the results of long-term Hase application on the gingiva of monkeys are slight, but significant. It is unlikely, however, that Hase is the most important mediator of periodontal destruction. This enzyme is more likely to be one of the many factors which, when com-

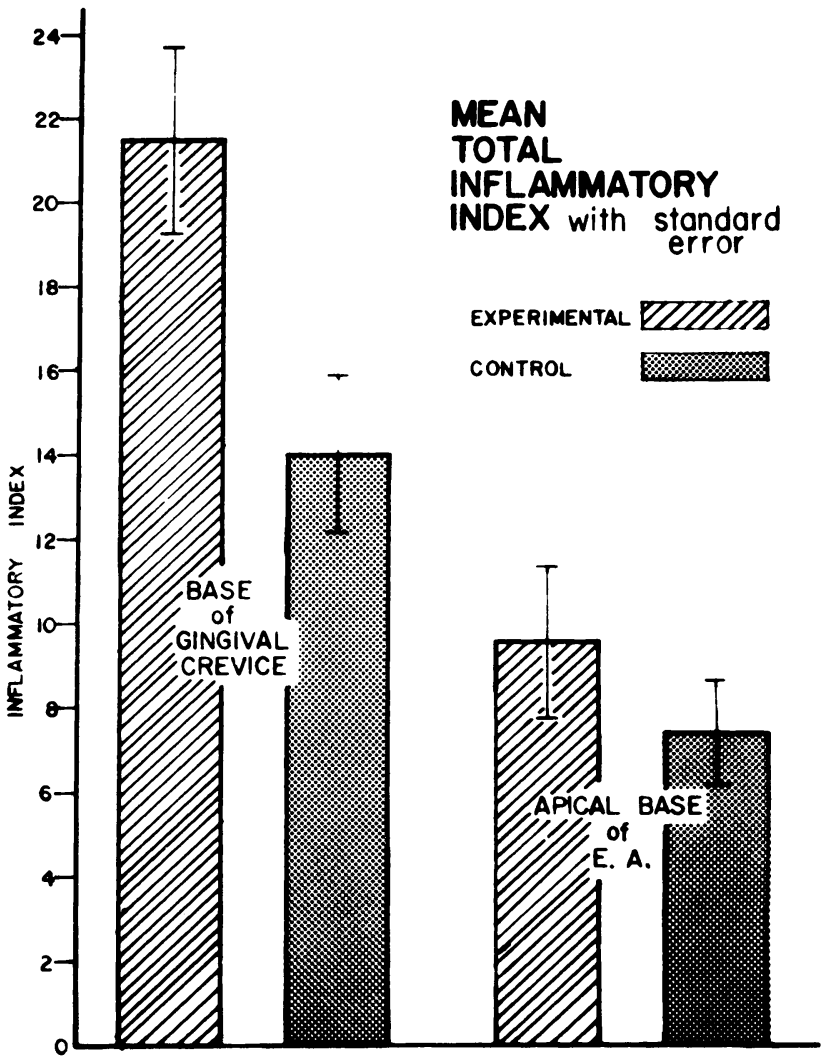

Figure 2. Mean total Inflammatory Indices with standard error bars.

bined and acting in concert, lead to the destruction of the periodontium.

\section{CONCLUSIONS}

1. Topical applications of Hase significantly increase the inflammatory cellular infiltrate at the base of the gingival crevice in rhesus monkeys.

2. Hyaluronidase topically applied does not result in the acceleration of the apical migration of the epithelial attachment or increase in the depth of the gingival crevice.

3. There consistently is a greater inflammatory cellular infiltrate at the base of the gingival crevice than at the apical base of the epithelial attachment.

* Department of Periodontics, The University of Michigan School of Dentistry, and VA Hospital, Ann Arbor, Michigan.

\section{BIBLIOGRAPHY}

1. Leung, S. W. The relation of calculus, plaque and food impaction to periodontal disease. J. Dent. Res., 41: 306-11, 1962.

2. Stahl, S. S. Etiology of periodontal disease. Pp. 129136. (In Ramfjord, S. P., et al., eds. World Workshop in Periodontics, 1966. Amer. Acad. Perio. and The Univ. of Mich., Ann Arbor, Mich., 1966). 
3. MacDonald, J. B., Gibbons, R. J., and Socransky, S. S. Bacterial mechanisms in periodontal disease. Ann. N.Y. Acad. Sci., 85:467, 1960.

4. MacDonald, J. B., and Gibbons, R. J. The relationship of indigenous bacteria to periodontal disease. J. Dent. Res., 41:320-26, 1962.

5. Scherp, H. W. Discussion of bacterial factors in periodontal disease. J. Dent. Res., 41:327-30, 1962.

6. Schultz-Haudt, S. D., and Scherp, H. W. Production of hyaluronidase and beta-glucuronidase by viridans streptococci isolated from gingival crevices. J. Dent. Res., 34: 924-29, 1955.

7. The production of chondrosulfatase by microorganisms isolated from human gingival crevices. $J$. Dent. Res., 35:299-307, 1956.

8. Dewer, Margaret R. Bacterial enzymes and periodontal disease. J. Dent. Res., 37:100-06, 1958.

9. Kjellman, O., and Söder, P.-O. Hyaluronidase activity of dental plaque material from diabetic and nondiabetic subjects. Odont. Revy, 21:251-260, 1970.

10. Nord, C.-E., Frostell, G., and Söder, P.-O. Hyaluronidase production by oral microorganisms. Svensk Tand. Tidskrift, 62:801-04, 1969.

11. Schultz-Haudt, S. D. Connective tissue and periodontal disease. Pp. 77-89. (In Hall, D. A., ed. International review of connective tissue research, Vol. 3, New York, Academic, 1965.)

12. Meyer, K., Hoffman, P., and Linker, A. Hyaluronidases. (In Boyer, P. D., et al., eds. The enzymes. Vol. 4, New York, Academic, 1960.) Pp. 447-60.

13. Muir, H. Chemistry and metabolism of connective tissue glycosaminoglycans (mucopolysaccharides). (In Hall, D. A., ed. International review of connective tissue research. Vol. 2. New York, Academic, 1964). Pp. 101-120.

14. Cimasoni, G., and Held, A. J. Intercellular mucopolysaccharides in human gingival epithelium. Arch. Oral Biol., 9:751-52, 1964.

15. Schultz-Haudt, S. D. Observations on the acid mucopolysaccharides of human gingiva. Oslo Univ. Press, 1957.

16. Thonard, J. C., and Scherp, H. W. Characterization of human gingival epithelial intercellular cementing substances. Abstr., J. Dent. Res., 38:711, 1959.

17. Wislocki, G. B., Fawcett, D. W. and Dempsey, E. W. Staining of stratified squamous epithelium of mucous membrane and skin in man and monkey by periodic acid Schiff method. Anat. Rec., 110:359, 1951.

18. Woessner, J. F., Jr. Acid hydrolases of connective tissue. (In Hall, D. A., ed. Inter. rev. of connective tissue research. Vol. 3. New York, Academic, 1965.) Pp. 201260.

19. Aisenberg, M. S., and Aisenberg, A. D. Hyaluronidase in periodontal disease. Oral Surg., Oral Med., and Oral Path., 4:317, 1951.

20. Schultz-Haudt, S., Dewer, M., and Bibby, E. G Effects of hyaluronidase on human gingival epithelium. Science, 117:653, 1953.

21. Thilander, H. The effect of leucocytic enzymes activity on the structure of the gingival pocket epithelium in man. Acta Odont. Scandia., 21:431-51, 1963.

22. Klingsberg, J., and Cutcher, E. O. Comparative in vivo effects of enzymes on rodent periodontium. Arch. Oral Biol., 7:603-20, 1962.
23. Murphy, P. J., and Stallard, R. E. An altered gingival attachment epithelium: A result of the enzyme hyaluronidase. Periodontics, 6:105-08, 1968.

24. De Ferrante, N. Turbidimetric measurement of acid mucopolysaccharides and hyaluronidase activity. J. Biol. Chem., 220:303, 1956.

25. Demetriou, N. A. and Ramfjord, S. P. Premitotic labeling and inflammation in the gingiva of rhesus monkeys. J. Periodont., 42:606-13, 1972.

26. Vaes, G. Hyaluronidase activity in lysosomes of bone tissue. Biochem. J., 103:802, 1967.

27. Alburn, H. W., and Whitley, R. W. Factors affecting the assay of hyaluronidase. J. Biol. Chem., 192:379, 1951.

28. Goggins, J. E., Fullmer, H. M., and Steffek, A. J. Hyaluronidase activity of human gingiva. Arch. Path., 85: 272,1968

29. Aronson, N. H., Jr., and Davidson, E. A. Lysosomal hyaluronidase. J. Biol. Chem. 240:PC3222, 1965.

30. Nord, C.-E., Söder, P.-O., and Lindqvist, L. Separation of hyaluronidases from dental plaque material by isoelectric focusing and properties of the enzymes. (Swed. Dent. J.) Svensk Tandläkare Tidskrift. 63:757-61, 1970.

31. Nord, C.-E., Söder, P.-O., Lundblad, G., and Lindqvist, L. Gelfiltration of hyaluronidases from dental plaque material through Sephadex and Bio-Gel columns. Odont. Revy, 20:397-404, 1969.

32. Nord, C.-E., Söder, P.-O., Lundqvist, L., and Frostell, G. Identification and purification of hyaluronidases from cultured dental plaque material. Odont. Revy, 21, 13-27, 1970.

33. Nord, C.-E. Properties of purified hyaluronidases from cultured dental plaque material. Svensk Tandläkare Tidskrift, 63:193-203, 1970.

34. Linder, L. and Nord, C.-E. Hyaluronidase activity in cultures of an anaerobic strain of corynebacteria and some properties of the enzyme. Scand. J. Dent. Res. 79: 523-527, 1971.

35. Linder, L., Nord, C.-E., and Söder, P.-O. Separation of hyaluronidase from a strain of anaerobic corynebacteria. Scand. J. Dent. Res., 79:528-532, 1971.

36. Kjellman, O., Linder, L., and Frostell, G. Effect in vitro of $\mathrm{pH}$ and low glucose concentrations on the growth and hyaluronidase activity of a strain of streptococcus mitis. Odont. Revy, 22:27-36, 1971.

37. Söder, P.-O., Nord, C.-E. Determination of hyaluronidase activity in dental plaque material. J. Perio. Res. 4:208-214. 1969.

38. Nord, C.-E. Fractionation of hyaluronidases from dental plaque material by ion-exchange chromatography and gelfiltration. Acta Odont. Scand. 28:223-232, 1970.

39. Nord, C.-E., Modeer, T., Söder, P.-O., Bergström, J. Enzymes activities in experimental gingivitis in man. Scand. J. Dent. Res. 79:510-514, 1971.

40. Söder, P.-O. The molecular size of enzymes from dental plaque material. J. Perio. Res. 4:215-222, 1969.

41. International Union of Biochemistry. Enzyme nomenclature, 1964. New York, Elsevier Publ. Co., 1965.

42. Awwa, I. A., and Stallard, R. E. The effect of lowered $\mathrm{pH}$ within dental plaque on the epithelial attachment. Inter. A. Dent. Res. Abstr., 48:135, March 1970. 